\title{
Citizen Participation in the Formulation of Public Policy in Mombasa County, Kenya
}

\author{
Stephen Kiruku Kamau', Daniel Mange Mbirithi ${ }^{2}$ \\ ${ }^{1}$ Student, Master of Public Policy and Administration of Kenyatta University, Kenya \\ ${ }^{2}$ Department of Educational Management, Policy and Curriculum Studies, Kenyatta University, \\ Kenya
}

\section{ABSTRACT}

To assist the government in determining its mandate, citizens should be involved as they best know their needs. The significance of citizen engagement in the process of policy formulation is rooted in among others, the fact that public policy outputs and effects affect those to whom the policy is targeted at. This study aimed to determine the effect of public participation in the public policy making process in Mombasa County, Kenya. The objectives of the research were to establish the modes of citizen participation used in public policy making process in Mombasa County, Kenya; to determine the main factors that influence citizen participation in public policy making process; to establish the implication of citizen participation in public policy making process and to determine the extent of citizen/ public participation in public policy making process. The study was guided by Good Governance Theory. The study utilized descriptive survey research design. The study targeted 560 County government and civil society representatives including women leaders, youth leaders and people living with disabilities representatives. The study used Yamane formulae to determine the sample size of 233 respondents. Purposive sampling was employed to select respondents. Data were collected through primary sources which include questionnaire, and interview schedule, while the secondary data were collected from the documentary sources. Data analysis involved both quantitative and qualitative methods. Quantitative data were analyzed descriptively and inferentially, and presented through frequency tables, pie chart and bar graphs. Qualitative data were analyzed by themes and presented through narration and pros forms. The findings of the study established that the main factors that affect citizen participation in formulation of public policy include direct benefits (financial, material), tangible or non-tangible to long or short term, among others. Other factors such as culture, history, government policy and social, political, and economic structures influence community participation. Also, the findings of the study revealed that citizens are well acquainted with public policy processes and there is effective county government guidelines and clear standards enhance public policy making processes. The study findings revealed that involvement in policy formulation is positively related to performance. Also, consultation enables easy supervision of work. The research also concluded that education is essential for both parties who are participating towards high quality public policy formulation as it would certainly reduce unnecessary manipulation and the problem brought on by lack of knowledge, accountability and transparency and understanding of each party's requirements. The study recommends that County Government of Mombasa should establish a participatory framework that allows citizens to monitor and evaluate development outcomes in the counties to ensure better decision making and implementation for subsequent projects and plans.

Key Words: Citizen Participation, Formulation of Public Policy, Mombasa County

DOI 10.35942/ ijcab.v5i4.213 
International Journal of Current Aspects, Volume 5, Issue 4, 2021, PP 90-107, ISSN 2616-6976

[IJCAB

\section{Cite this Article:}

Kamau, S., \& Mbirithi, D. (2021). Citizen Participation in the Formulation of Public Policy in Mombasa County, Kenya. International Journal of Current Aspects, 5(4), 90-107. Retrieved from https://journals.ijcab.org/journals/index.php/ijcab/article/view/213

\subsection{Introduction}

Public participation is the implementation of the strategy is vital for supporting majority rules system and advancing great nearby administration and organization (Closet, 2016). Public investment empowers a "bottom-up" way to deal with the public policymaking measure (Fox and Meyer, 2015). A "bottom-up" approach to manage public participation in approach making similarly engages limit building (Kotze and Kellerman, 2013). The pooling of HR together at the grassroots level prompts limit building. Total decisions taken on a particular close by issue by a social affair of occupants have more strength rather than those taken by an individual.

\subsection{Citizen Participation}

This is an association that allows private individuals to affect public decisions and has for a long while been a piece of the lion's share rule dynamic cycle. The fundamental establishments of occupant interest can be followed to old Greece and Colonial New England. Before the 1960s, authoritative cycles and frameworks were planned to energize "outside" participation. Resident cooperation was organized during the 1960s with President Lyndon Johnson's Great Society programs (Anderson, 2015). Citizen participation is likewise depicted as the inclusion of residents in a wide scope of exercises that identify with the making and usage of strategy including the assurance of levels of administration, spending needs, and the agreeableness of actual development projects to situate government programs towards local area needs (Fox and Meyer, 2015). In Canada, the nation has different discussions where communities and residents can communicate their perspectives on open approach issues and these include: going to public interview bunches on the arrangement issues being referred to; Government started referenda; Elections; Legislative hearings; Contacting media; Community gatherings; Royal Commissions; Town corridor gatherings; Surveys and assessments of public sentiment; Policy round tables; Petitions, exhibits, letter-composing efforts or other support procedures (Campbell and Marshall, 2017). In Switzerland, before any choice ought to be taken government consistently leads a submission, it shows that individuals do have a say in any administration choice (Gaventa and McGee, 2016). An empowering advantage for this positive advancement is that the number of inhabitants in Switzerland is exceptionally low.

The Australian experience shows that administration services and offices draw in residents in the arrangement plan measure (Holmes, 2011). For example, the Department of Industry, Tourism and Resources submits its officials to six parts of a meeting interaction corresponding to strategy plan and execution. When creating strategy guidance, they counsel generally; give sensible time periods to its residents to react to strategy recommendations; clarify the cycle; and guarantee that the commitment to strategies is adjusted and applicable to the Government's more extensive monetary and social targets. In the wake of settling on approach choices, they give data to residents about choices that influence them; and residents would then be counseled during the usage of (Curtain, 2016). The Armenian government has started various endeavors since independence just as authoritative arrangements pointed toward making and cultivating resident government direct participation. The arrangement of neighborhood self-administration has arisen because of 1995 RA Constitution arrangements, 1995 Law on Administrative Territorial Division and was 
additionally reinforced by the 1996 Law on Self-Government, just as by a few other protected changes. The subsequent stages were made by the approval of the European Charter of Local SelfGovernment in 2002 and Utrecht Protocol in 2013. The two archives planned to advance the authoritative and monetary autonomy of nearby networks, just as make space for residents' immediate inclusion in the networks (Halachmi, Arie and Marc, 2010).

However, the majority rule substance of administration in Africa is as yet a matter of genuine concern both inside and outside of Africa. As indicated by Sharma (2019a), the political scene in present day Africa is unfortunately one of desperation and misery, for popular government and political steadiness appear to be tricky as downpour in a period of dry spell. UNDP (2017) further add that numerous nations in Africa have had long chronicles of either military standard portrayed by overthrows and counter-upsets, or a tyrant one-party framework. Additionally, Sharma (2019b) contends that different nations are as yet under a monarchical arrangement of government coinciding next to each other with feeble organizations of delegate majority rules system. The idea of public participation in Botswana can be followed to the pre-autonomy time where the local area was viewed as a feature of the dynamic designs where the town initiative looked for thoughts and counsel from local people preceding presenting strategies and projects (Molokwane and Lukamba, 2018). Gabriele (2017) takes note of that Botswana has a solid practice of support and interview at all custom of public life from the town to the focal government, and this, has solid roots from the Tswana custom of holding 'town gatherings' known as the Kgotla which actually exists and is important for the neighborhood consultative organization. Cristina and Bianca (2016) balance Botswana with other Sub Saharan African nations recognizing that the nation is novel as it received a pluralist political framework that ought to normally uphold the detailing of strategy by vested parties. Correspondingly, Anderson (2015) brings up that while arranging in Botswana was midway imagined, there is proof to show that strategies were and keep on being truly established in the custom individuals and this has expanded support in strategy and arranging activities.

Significant public participation in administration is a critical element for public changes that were organized by the Constitution of Kenya (CoK, 2010). Article (1) of the Constitution vests all sovereign capacity to individuals of Kenya. This force can be communicated through direct investment or in a roundabout way through chosen agents. Also, different bits of enactments securing devolution feature the standards of resident interest. Together, these established and authoritative arrangements profit different stages for resident support in degenerated administration (Cleophas and Ephantus, 2016). Resident cooperation is one of the public qualities and is additionally one of the standards of public help as expressed in the Constitution in Articles 10 (2,a), Article 35(1) and (3) and Article 232 (1). Article 174 of the constitution gives the forces of self-administration to individuals and upgrades the interest of individuals in the activity of the forces of the State and in settling on choices influencing them. Citizen participation is not some help however an established commitment that the two degrees of government should stick to. It should be obviously characterized by the County government in concurrence with the residents to accomplish acceptable outcomes. The public authority should concur with the residents on measures, strategies, section levels, protections to residents' choices and ensures that their requirements and needs will start things out (KHRC and SPAN, 2010). In spite of these clear constitutional and administrative arrangements, there has been a clamor the nation over specific choices which have been made by provinces in the course of the most recent three years (KHRC and SPAN, 2010). In various districts, residents have indicted their County governments over issues going from Finance Bills, which attribute tolls to be charged for different County administrations, to distinguishing proof and usage of activities. A few provinces have had their 
Finance Bills revoked by the courts while different areas have had dispensing of assets for advancement projects deferred because of protests radiating from the residents (Cleophas and Ephantus, 2016).

\subsection{Policy Formulation Process}

A policy can be portrayed as a purposive system taken by individuals with huge impact in the journey for explicit destinations or objectives. Examples of vital destinations or objectives are to determine explicit issues in the public field like HIV/AIDS, vulnerable guidance organizations, energy crisis, destitution and debasement, among others (Buse, Mays and Walt, 2012). Strategy detailing insinuates the route toward recognizing approaches, often called decisions or decisions, to decide issues took a gander at by a particular affiliation (Anderson, 2014). Framing a procedure comes in light of methodology demands or claims for action on a particular issue that are made by various performers. The performers could be occupants, customers or the regular society, among others. For example, the interest could be made to block certain activities inside the neighborhood affiliation. As a result of these game plan demands, specialists like government ministers, MPs, party specialists and companions' bosses make decisions that give direction on what should be done. The decisions may be to approve a standard, issue boss requests, make administrative standards or make legitimate interpretations of laws (Howlett, 2015).

The way toward forming an approach incorporates the action of power by different individuals and get-togethers. These gatherings put some sort of pressing factor or power in the arrangement detailing measure. The power comes from the accompanying entertainers: Individual occupants in a delegate share rules framework, it is acknowledged that power streams from people (solitary inhabitants). This includes that capacity to detail systems is relegated from people to specialists who structure the gathering and subsequently characterize approaches to assist people. For the present circumstance, people start the collaboration of technique plan by ruling for contenders whose notions and characteristics they know. Indeed, the part of oppressing certain office-holders to intermittent races guarantees that consideration is paid to the interest of the individuals who are addressed. Through the council, the delegates of individuals' detail arrangements by a greater part vote (Howlett and Mukherjee, 2017).

Political parties on account of public approaches, ideological groups fill in as connections among residents and government strategy creators. First and foremost, ideological groups will in general have projects or manifestoes that they present to the residents. Conventionally, individuals would decide in favor of a specific gathering dependent on its program instead of people. The electorates expect that the gathering they vote in favor of, whenever chose for office, will form strategies on vows made in the political race proclamation. Furthermore, the gathering that successes the races is relied upon to actualize its program while resistance groups should introduce elective projects. At this stage, the decision of public approaches can be affected by practicing power over party authorities who are in government like the President and Vice-President, among others (Mkandawire, 2014). Pressing factor bunches are formal designs whose individuals share a typical interest. Instances of such gatherings incorporate common society associations. These gatherings endeavor to impact the choices of the public authority without endeavoring to possess political office (Howlett and Mukherjee, 2014).

Notwithstanding pressure bunches placing power in the approach detailing measure, they are not authority strategy formulators. Official approach formulators are those authorities who have the lawful power to figure arrangements. These authorities include: Legislatures who are the 
incomparable approach making assortments of associations particularly in government. For instance, the council in an administration framework would be the National Assembly/Parliament. Additionally, different associations, for example, ideological groups and business organizations likewise have assemblages of comparative standing, that is, the preeminent approach making organs. These incorporate public shows and top managerial staff, separately (Peters, 2015). The Executive is the organ of an association that is answerable for actualizing arrangements. For instance, in an administration framework, this organ is generally headed by the president and contains a few government services and divisions. This organ takes an interest in arrangement detailing on the grounds that the council will in general delegate a generous measure of strategy definition power to the president. Likewise, different associations like ideological groups will in general have organs that are accountable for executing arrangements and would have appointed position to make approaches in specific regions. For instance, the leader would be offered ability to settle on choices and regulatory arrangements that would encourage powerful usage of strategies (Mkandawire, 2014). The Judiciary separated from implementing the law, the legal executive in a vote based state assumes a critical part in arrangement definition. The courts, particularly the Supreme Court assumes this part through legal survey of laws. Legal audit alludes to the force of the legal courts to decide the lawfulness of activities of the governing body and leader and proclaim them invalid and void if such activities don't adjust to the established arrangements. In such manner, when an adjudicator deciphers the significance of administrative arrangements then his/her translation turns into the strategy for the issue being challenged (Peters, 2015).

The significance of conferences and association of accomplices in the game plan enumerating measure is to make the sensation of procedure ownership among accomplices. Thusly, it enables the accomplices to believe them to be as reflecting their feelings or necessities. If there is limited or nonattendance of consideration of accomplices, the affected accomplices may consider the to be as inconsequential. This is because it very well may be seen as blamable of their philosophical inclinations. The result would be strong protection from the methodology. Finally, there would be a need to encounter the definition cycle again to make the methodology all the more remarkable or to dispense with bundles that appear by all accounts, to be incapable/hostile (Anderson, 2015). However, despite the fact that legislatures elevate their residents to take part in policymaking, direct inclusion in policymaking is regularly maintained a strategic distance from (Antonini and Fini, 2011). One explanation behind little cooperation in policymaking is that in spite of excitement for significant and helpful public arrangements, residents regularly feel that their voice will basically not be heard, and investment will incite no progressions inside the public authority (Fowler and Kam, 2007). For instance, in huge populaces the likelihood that a solitary demonstration of support will essentially influence the result is little. From this objective decision point of view of cooperation, essentially appending an incentive to the possibility of popularity based support is not powerful at cultivating public commitment.

\subsection{Statement of the Problem}

In Kenya, most open organizations are described by mystery, prohibitive measures and absence of admittance to data held by strategy making and strategy execution government foundations. This situation prompts basic liberties infringement, maltreatment of force, an inert culture and absence of admittance to any data in regards to the public policymaking measure held by the public authority organizations (Leedy, Brynard and Hanekorn, 2017). A cryptic and inert culture is additionally an immediate danger to local area advancement. Nonetheless, if public cooperation is inescapable in Kenya and for the most part Mombasa County everywhere, it will help keep the 
rulers responsible to individuals and will forestall strategy producers from making strategies that are negative to the overall government assistance of the local area. Government projects without community participation takes on a little color. In addition, participation of beneficiary's main advantage of protection and control areas have established the continued exploitation. Participatory approaches and methods motivate people to agree on a strategy of economic and social development planners. Individual participation in the community development process is meant to encourage them to implement programs and projects (Conklin et al., 2015). Past investigations have zeroed in on the part of setting in approach and program arranging (Boivin, 2014). Others likewise distinguished the conceivable result of public participation (Restall \& Kaufert, 2011; Carman et al., 2015). Despite the fact that there has been an expanding number of investigations of public support in the public policymaking measure, no examinations have zeroed in on the impact of resident interest in the public policymaking measure in Mombasa County. Understanding these components would help the province organization and chiefs to amplify the advantages of public investment in the field of the public policymaking measure in Mombasa County. Therefore, this study aimed to determine the effect of citizen participation in formulation of public policy in Mombasa County, Kenya.

\subsection{Objectives of the Study}

i. To establish the modes of citizen participation used in formulation of public policy in Mombasa County, Kenya.

ii. To determine the main factors that affect citizen participation in formulation of public policy process in Mombasa County, Kenya.

iii. To establish the effects of citizen participation in formulation of public policy in Mombasa County, Kenya.

iv. To determine the extent of citizen participation in formulation of public policy in Mombasa County, Kenya.

\subsection{Literature Review}

\subsection{Theoretical Framework}

The study underpinned by Good Governance Theory. Good governance theory was founded by Bjork and Johansson in 2001. The theory recommends that some fundamental norms according to which a respectable government, whatever its design, ought to be run. Such guidelines consolidate duty, control, responsiveness, straightforwardness, public speculation, economy, and capability. The hypothesis of good administration is made to mirror all the standards articulated above and some more (Minogue at al., 1998). Good governance is about how people are managed not just as customers or buyers (as in the new open organization approach) yet as inhabitants, who save the advantage to consider their lawmaking bodies answerable for the moves they make or disregard to take. The interest in efficiency in the public zone should not to be allowed to incite horrendous help. When there is horrendous help, inhabitants hold the advantage of dispute and consider officials dependable (Gisselquist, 2012).

The hypothesis was appropriate as its guidelines helps the cognizance of this survey and used as documents to check or assess the public approach making measure in Mombasa County. Along these lines, a real understanding of the theory of good organization and its guidelines is the sine qua non to a proper game plan and examination of occupant interest and public methodology making measure in Mombasa County. This is extremely fundamental with the end goal of making 
expansive recommendations for development just as the possible ramifications for citizen participation and public policy making process in Mombasa County.

\subsection{Empirical Review}

\subsubsection{Modes of Public Participation}

Public participation is portrayed as the inclusion of residents in a wide scope of exercises that identify with the making and usage of the arrangement including the assurance of levels of administration, spending needs, and the worthiness of actual development projects to situate government programs towards local area needs (Berner, Amos and Morse, 2011). Anderson (2015), resident contribution implies the publics' capacity to partake or take part in the country states' cycles and exercises particularly concerning the readiness of public arrangement and the basic dynamic that influences their everyday lives. As per Obasi and Lekorwe, (2014) different researchers are in understanding that resident commitment alludes to ways, exercises or cycles for including residents in the public approach measure. Fundamentally, resident inclusion involves the commitment of residents as members in the improvement of public exercises, for example, public policymaking measure.

Worldwide, public participation takes numerous modes and measurements. A portion of the modes incorporate races, interview, vested parties, ideological groups, proficient gatherings and the business area. The degree of larger part rule government is associated with the basic chances that exist in a nation like an advantage to private ownership. This advantage engages people to check out the unregulated economy course of action of advantage, natural market (Devas and Grant, 2015). Moreover, the relationship between the unregulated economy structure, personal business and vote based framework has certain implications for interest and the public policymaking measure. Finance managers go about as strategy guides to public policymakers (International Peacebuilding Advisory Team, 2015). In this way, finance managers are in a more grounded position than another pressing factor bunch since they generally have more cash, instant association and their good position give them particular admittance to public cooperation in the public policymaking measure. In both created and agricultural countries, conference includes a cycle of correspondence between the public authority and the represented in managing a public issue (Davids, 2018). The discussion likewise alludes to the way toward looking for data or counsel. Meeting between the neighborhood government and members is a two-way measure: each has something different needs. Accordingly, meeting is a type of support where data is made accessible and assessments of members are inspired.

In most African nations, a vested gathering fills in as a mouthpiece for a specific nearby assembling in the public eye (Anderson, 2015). In view of ordinary interests or a particular premium that is affected by government decisions, vested gatherings attempt to affect methodology making foundations by oral or created depictions. The exercises of vested gatherings are pointed generally at propelling the interests of their people (Cristina and Bianca, 2016). Thus, vested parties empower policymakers to take comprehension of the common perspectives, realities and qualities to build up significant needs for general fulfillment locally. In Kenya, casting a ballot has been utilized for the most period in resident investment. Casting a ballot can be depicted as an interaction through which the electorate pick among competitors who are qualified for a specific opportunity (Gabriele, 2017). Projecting a polling form in races is seen as the central sort of open speculation truly coming to fruition and use of methodology at the local government level. The standard is that in a dominant part rule neighborhood government, races are held at time periods 
longer than five years, to give the enlisted residents a possibility of imparting the underwriting or disappointment concerning the way where the picked specialists have acclimated themselves with their work (KHRC and SPAN, 2010). Hence, the voting booth is the channel through which the electorates take part in the approach choices of the public authority of the day.

\subsubsection{Factors that Influence Public Participation in Public Policy Making Process}

Burton (2015) surveyed various investigations and contends that there is a need to create proportions of successful interest to give a powerful evaluation of the putative advantages of public participation. He expresses that procedural standards have supplanted instrumental advantages in making a decision about the advantages of support and subsequently that there is a need to discover hearty estimations of the advantages. He proposes seven general classes: developed confidence of members; expanded information and consciousness of parts of common and political life; expanded mindfulness and comprehension of own personal matters; a chance for articulation of key components of individual social character, for example as communist, traditionalist, women's activist, and internationalist. Matharu, Sullivan and Skelcher (2016) built up a hypothetical system to investigate ideas of mobilization, construction and inclusion (MCI) of European organization entertainers (England, Germany and France), asking who is incorporated and how individuals are amassed. They also ask how specialists are picked, how network performers are created and how this affects instances of thought and shirking. They battle that thought revolves around rules and institutional arrangement, through which certain publics are ascribed validness and others denied it. They express that the components for non-uphold are normally explained by uncalled-for workplaces, nonappearance of information, gatekeeping by existing local area pioneers, absence of city mindfulness or limit.

An investigation of Italian local governments by Azfar (2011) found that administrations that were more open to constituent pressing factor, overseen and conveyed benefits all the more proficiently. Another examination in Colombia by Fiszbein (2017) found that local area interest expanded requests for powerful nearby governments and furthermore opened the window for building the limit of the residents. An investigation by Isham and Kähkönen (2016) on request responsiveness of decentralized water administration conveyance in Central Java, Indonesia found that just if clients were straightforwardly associated with administration plan and choice, were benefits liable to coordinate clients' inclinations. Educated cooperation saw family units willing to pay for costlier advances than the pioneers would have decided for them. A study directed in 14 networks in Armenia by ERDSC (2014) uncovers the accompanying data: a tremendous segment (36\%) of the respondents accepts that nearby networks work insufficiently and non-straightforwardly, just $11 \%$ of individuals referenced that they had at any point taken part locally undertakings. It is unavoidable that low trust and absence of commitment portray people's withdrawal in neighborhood organization.

Naidoo and Ramphal (2018) tried to decide the components that influence public investment (PP) for powerful civil assistance conveyance by talking ward council individuals in the Ekurhuleni Metropolitan Municipality in South Africa. Information were gathered utilizing a semi-organized poll, and factor examination and underlying condition demonstrating were finished. Seven elements were assembled as (1) assistance of administration conveyance (SD) factors (i.e., public cooperation; responsibility and straightforwardness; individuals' centeredness; correspondence; sex portrayal; and solid connections) and (2) factors that hinder administration conveyance. The examination found that area, race, and information on the Batho Pele standards decided the impression of SD. It further found that the assistance elements of PP for viable SD ought to be 
energized, while power battles should be limited for viable SD in South Africa. Abraham (2014) did an investigation on resident participation and its effect on decentralized assistance conveyance. Utilizing cross-provincial optional information this investigation surveys the effect of direct resident cooperation on decentralized assistance conveyance in Kenya in the time frame 20022010. This was as accommodated under the Local Authorities Service Delivery Action Plan (LASDAP). The impact of support was surveyed as far as what it means for the proficient portion of assets; responsibility and decrease of debasement; and, value in help conveyance. The investigation found that the cooperation of residents has been insignificant and the subsequent impact on the decentralized assistance conveyance immaterial. The investigation reasoned that regardless of the inauspicious effect of resident interest, the initial move towards regulating support has been made whereupon current designs of County governments should expand on.

\subsubsection{Implication of Public Participation in Public Policy Making Process}

In democratizing the directing cycle, public participation passes on significant information about open necessities and solicitations from everyone to methodology makers and implementers and the opposite way around. At the same time, it raises responsiveness to public necessities and empowers the patterns of procedure use and neighborhood (Bekker, 2015). Public investment in open arrangement making and strategy usage likewise holds public functionaries within proper limits (Cloete, 2016). Irvin and Stansbury (2014) directed an experimental examination to discover the effect of resident investment upon American establishments and the existence of those urban communities. The examination uncovered that there's a genuinely solid connection between the measure of and nature of resident investment in these urban communities and personal satisfaction and nature of dynamic. As per Obasi and Lekorwe (2014), in Britain, strategy causing spaces for resident commitment to include stages like studies. For example, a review of various types of public cooperation in 216 neighborhood governments uncovered that $92 \%$ of the nearby governments utilized assistance fulfillment studies while $86 \%$ utilized objections/recommendation plan while in numerous nearby governments different types of public investment are broadly utilized (Markus, 2018).

Talpin (2017) talked about participatory planning in Spain, France and Italy. His paper examines power relations and the issues of systems, outlining of conversations and execution of choices. The investigation depended on two-year member perception and top to bottom meetings in three district contextual analyses in the three nations. In the French city, 'neighborhood chambers' were set up to choose about $20 \%$ of the city speculation spending plan. City-wide topical workshops were likewise settled zeroing in on metropolitan arranging, instruction, and so forth in the Italian district, the region was partitioned into eight 'social areas' and public gatherings were coordinated to choose what nearby undertakings would be supported from the financial plan. In the Spanish city, there were three degrees of participatory gatherings at neighborhood, region and city levels, the focal component being the 'zone congregations' at the local level which settled on which proposition and tasks to advance to the more elevated levels. The examination presumed that in spite of the participatory talks and altruism of nearby legislators, their impact regularly stays overpowering in participatory spending congregations.

An investigation of the Cebu City in the Philippines by Rakodi (2016) inferred that neighborhood levels of portrayal give channels to counsel, support and responsibility as well as making the organization more successful and available to inhabitants. What's more, as Hart (2012) additionally put it, the essential legitimization of decentralization by its promoters is that it makes an ideal condition for resident support. Moreover, as Rondinelli (2015) noticed, decentralization is pushed 
as a method of inspiring boundless support in the dynamic considered crucial for the advancement interaction. Furthermore, it is especially expected to organize the interest of residents being developed arranging and the board. The presumption as per Hart (2012) is that support creates better residents on the grounds that through investment they understand their true abilities. Hallman (2016) further demonstrated that one reason for decentralization is to accomplish better associations with residents. Therefore, resident commitment in the public approach measure has come to be seen properly as a fundamental fixing and characteristic of a feasible participatory popular government. Hence, resident investment is typically viewed as an important component of vote based citizenship and popularity based dynamic (Michels, 2011).

Investigating participatory projects in many non-industrial nations including Nepal and India, Mansuri and Rao (2013) inferred that participatory arranging creates 'more excellent activities that are better lined up with local area needs, and guarantees more comprehensive administration just as more prominent value in advantage sharing. Notwithstanding, they alert that interest results fluctuate extensively relying upon local area qualities like abundance disparity, ethnic heterogeneity, the board encounters and the job of focal organizations. By and by, a few researchers have discovered that investment may have positive as well as negative impacts or once in a while no impact on neighborhood arranging by any means. In a meta-investigation with an example of 100 cases, Gaventa and Barrett (2010) presumed that in the 828 results contemplated, $75 \%$ were positive and 25 percent were negative. The positive results incorporated the making of a feeling of citizenship and organization and strengthening of residents; fortifying of interest practices and extending organizations and fortitudes; reinforcing mindful and responsible states and the advancement of comprehensive and firm social orders. Notwithstanding, in every classification, it likewise created negative outcomes including disempowerment and reinforcement of social hierarchies and exclusion.

\subsubsection{Extent of Public Participation in Public Policy Making Process}

As per Devas and Grant (2015), all together for the public authority to effectively pick what to do, the residents ought to be included since they know and make certain of what they need from the public authority. Public investment is seen as one of the achievements of vote based system and neighborhood administration. Public cooperation really taking shape and execution of strategy as such is irreplaceable for supporting majority rules system and advancing great nearby administration and organization (International Peace Bundling Advisory Team, 2015). Furthermore, resident interest fortifies government relations with residents and is a thorough interest in better strategy making and a center segment of good administration. The Swedish International Development Cooperation Agency (2016) underlines that investment is reflected as one of the characteristics of popularity based government. This is on the grounds that participatory majority rules system offers a component for remembering individuals to be included for the overseeing techniques of government. Neighborhood government is the nearest to the general population for permitting participatory vote based system to show, public cooperation further advances vote based standards like political balance, lion's share rule, well known power and famous meeting. Agreeing with the above sees is Davids (2018) who expresses that public investment indicates a comprehensive cycle pointed toward extending majority rule government through formal participatory systems.

In South Africa, a solid perspective on open cooperation is thought about in the neighborhood government during the Integrated Development Plan (IDP) (Molokwane and Lukamba, 2018). The nearby power should offer the local area a chance to make an info concerning the IDP which is a 
five-year plan. The nearby specialists can't actualize any program without getting the local area contribution on the IDP. This is a typical cycle as indicated by South African enactment; the local area ought to be counseled. The South Africa constitution specifies that the general population or the local area is to be urged to take an interest in policymaking. In Kenya, resident contribution in approach definition agrees residents a chance to impact public choices. Notwithstanding this, the part of individual residents is restricted to thinking about strategy issues and planned arrangement choices. The forswearing of people in general to take an interest in arrangement plan is frequently connected to how the public authority sees a 'resident'. Berner, Amos and Morse (2011) see that a resident is rather the proprietor of the public authority and thusly, residents are not simply the majority following the elites being the public authority. They have control and can positively control the public authority. In that capacity, including residents at the arrangement plan stage gives a chance to residents to have their administration settle on options educated by their info.

\subsection{Conceptual Framework}

\section{Independent variables}

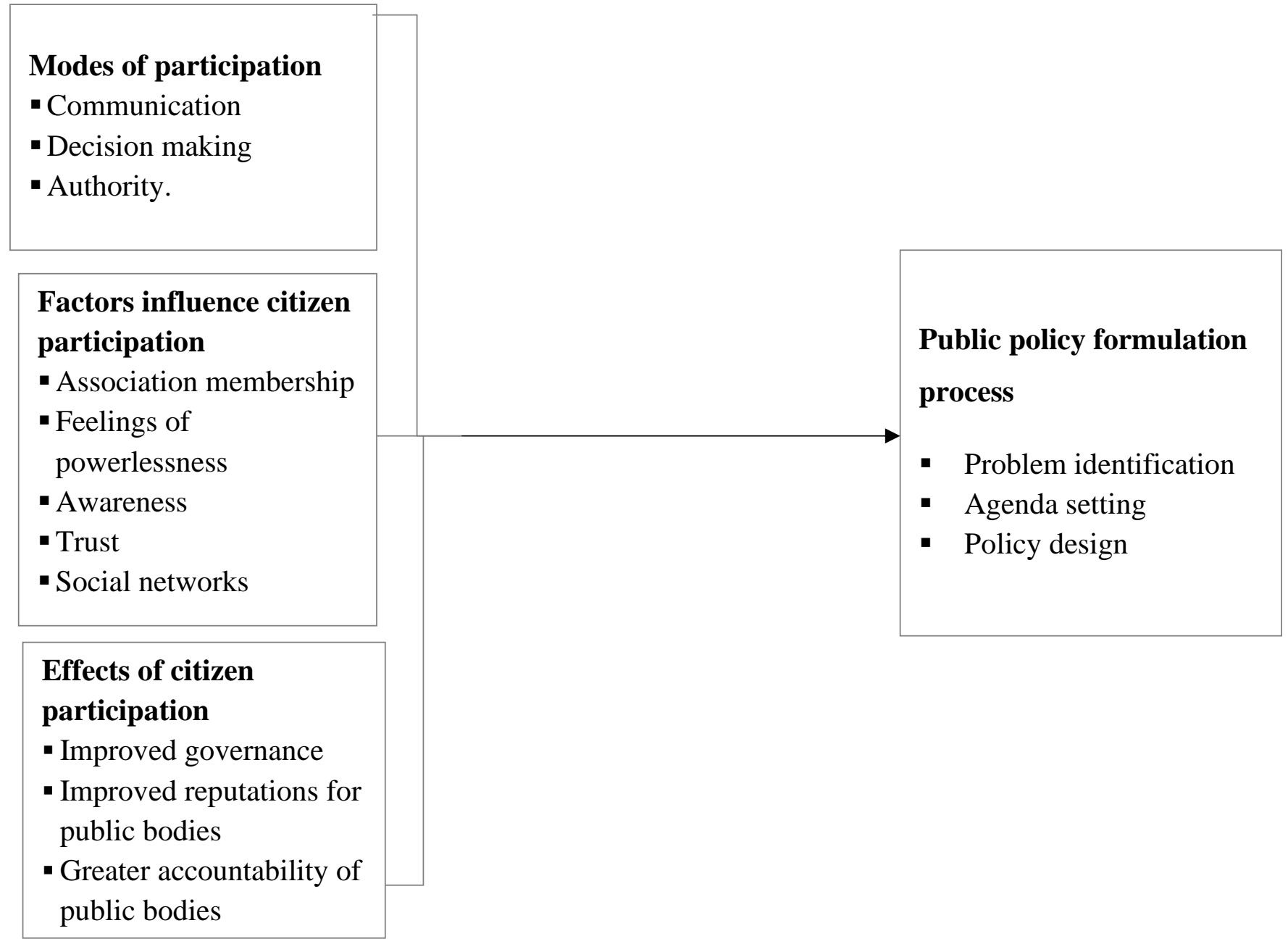

Figure 1: Conceptual framework

Source: Researcher (2021) 


\subsection{Research Methodology}

The area of study was Mombasa County and is one of the forty-seven County Governments in Kenya. Mombasa County is one of the counties with reported cases of citizens not participating in policy making (Korir \& Kipkemboi, 2014). As such, the County is therefore an integral part of a country's national governmental system. Likewise, Mombasa County provides basic services like sanitary services, health services, water supply and protection services to the community (Wolf $e t$ al., 2014). Mombasa County was selected because previous to the formation of County Governments, it was the oldest city in Kenya and the second largest city in terms of population. It is also important to know how the County government involves its population on matters concerning public policy making process with regards to the 2010 Kenyan constitution, and the citizens' role in the overall quality of governance. The survey utilized a descriptive research plan as a review plan.

In carrying out this study, the staffs of County government, civil society representatives which includes women, youth leaders and people living with disabilities representatives were involved in this study. These respondents were selected because; the County Government is responsible for making the public policies, the civil society organizations are best placed to lobby for citizen participation in the public policy making process while the youth group and persons living with disabilities stand to lose more where they are not involved in the public policy making process. These groups could provide sufficient information on factors that influence their everyday-life decisions and how they can help improve public policy making process. Purposive sampling was utilized in choosing respondents for this investigation. In the sampling technique, the sample size in essence is viewed as less fundamental than the rules used to pick the example. The supposition behind purposive sampling is that by utilizing practical insight and a proper procedure, the researcher can handpick the cases to be incorporated and create samples that are good. The sample size was controlled by the utilization of the Yamane (1967) equation for determining sample size. The study sample size was 233 respondents. This represent $41.61 \%$ of the target population. Data were collected through primary sources which include questionnaire, and interview schedule; while the secondary data were collected from the documentary sources. Data analysis involved both quantitative and qualitative methods. After an intensive perusing of information, the researcher endeavored to create classes or codes and reducing the voluminous information into sensible arrangements of themes. The information was coded and entered into the Statistical Package for Social Sciences (SPSS) version 23. Descriptive examination of quantitative information was utilized with frequency tables and rates. The data were organized presented into percentages using frequency tables.

\subsection{Data Analysis Results}

The researcher carried out multiple regression analysis to determine the relationship between citizen participation and formulation of public policy in Mombasa County, Kenya. The findings are displayed in the following sections;

Table 1: Modal Summary

\begin{tabular}{lllll}
\hline Model & R & R Square & Adjusted R Square & Std. Error of the Estimate \\
\hline $\mathbf{1}$ & 0.919 & 0.845 & 0.847 & 0.111 \\
\hline
\end{tabular}

Source: Field Data (2021) 
The findings in Table 4.7 indicate the model summary. From the findings, $\mathrm{R}$ was 0.919 , adjusted $\mathrm{R}$ square was 0.847 and $\mathrm{R}$ squared was 0.845 . An $\mathrm{R}$ square of 0.845 implies that $84.5 \%$ of formulation of public policy in Mombasa County, Kenya are explained by the independent variables of the study. However, there are other factors that affect formulation of public policy that are not included in the model which account for $15.6 \%$. An R of 0.919 on the other hand signifies strong positive correlation between the variables of the study.

Table 2 ANOVA

\begin{tabular}{lrllll}
\hline Model & \multicolumn{1}{l}{ SS } & df & MS & F & Significance \\
\hline Regression & 235.45 & 4 & 715.1 & 4.17 & 0.001 \\
Residual & 67.43 & 181 & 0.745 & & \\
Total & $\mathbf{3 0 2 . 8 8}$ & $\mathbf{1 8 5}$ & & & \\
\hline
\end{tabular}

Source: Field Data (2021)

From the ANOVA Table 4.8, the study was done at 5\% significance level which is 0.05 . The research provided a P-Value of 0.001 which is lower than the significance level of 0.05 , therefore statistically significant. This implies that citizen participation significant influence formulation of public policy in Mombasa County. The overall regression model was significant and therefore a reliable indicator of the study findings. Also, $\mathrm{F}_{\text {Calculated }}$ was 2 and $\mathrm{F}$ Critical was 1.84, thus $\mathrm{F}_{\text {Calculated }}$ $>\mathrm{F}_{\text {Critical }}$ an indication that the overall regression model was significant for the study.

The first objective of the study was to establish the modes of citizen participation used in formulation of public policy in Mombasa County, Kenya. The findings established that $39 \%$ of the participants noted that access to information as mode of citizen participation to formulation of public policy, $34 \%$ consultation and $27 \%$ indicates active engagement through dialogue and partnership. The policy formulation is part of the pre-decision phase of policy making. The best practices and principles the County has implemented include informing the citizen through provision of information that will assist them in understanding options, issues, and solutions; public consulting in order to get feedback on possibilities or decisions; public involvement to ascertain issues are factored in during the process of making decisions especially in coming up with a decision-making guide and alternatives.

The second objective of the study was to determine the main factors that affect citizen participation in formulation of public policy process in Mombasa County, Kenya. The study findings revealed that the main factor that affect citizen participation in formulation of public policy include direct benefits (financial, material or otherwise), tangible or non-tangible to long or short term, among others. Other factors such as culture, history, government policy and social, political and economic structures influence community participation. Poorly designed and inadequate measures for information, consultation and active participation in policy making can undermine government relations with the citizens. The participation of public in policy formulation can be effective only when that decision can have an impact in their community.

The third objective of the study was to establish the effects of citizen participation in formulation of public policy in Mombasa County, Kenya. The findings of the study revealed that majority of the participants agreed that citizens are well acquainted with public policy processes, there is effective county government guidelines and clear standards enhance public policy making processes, there is adequate human and financial resources facilitate public policy mechanisms, 
there is support for the implementation of public policy making skills through technical expertise and capacity building and there is development and dissemination of citizen participation leads to better public policy processes within the county governments as supported by a mean of $3.63,3.55$, $3.47,3.65$ and 3.46 respectively.

The fourth objective of the study was to determine the extent of citizen participation in formulation of public policy in Mombasa County, Kenya. The findings of the study revealed that that $46 \%$ of the respondents noted that citizen participation in formulation of public policy at great extent, 39\% moderate extent and $15 \%$ no extent. Involvement of the public has been reported to increase the quality of decisions since it promotes levels of awareness among the stakeholders involved. Public participation provides a forum for both decision makers and stakeholders to enable understanding the range of issues and viewpoints.

\subsection{Conclusions and Recommendations}

\subsection{Conclusion}

From the study findings, the study concludes that the participation of citizens in the formulation of public policies is of great significance. All citizens should participate in the formulation of public policies. However, there are still some difficulties in real life that make it difficult for citizens to participate in the formulation of public policies. Firstly, the awareness of citizen participation is not strong. Secondly, citizens lack corresponding capabilities. In addition to subjective reasons, there are also objective reasons. The mechanism of citizen participation in public policy formulation is not perfect and information asymmetry exists in the process of citizen participation.

In order to strengthen and maintain good relations amongst the citizen and the government effective citizen participation must take place. Additionally, citizen participation provides a twoway learning process where the government learns from the consultative feedback from citizens and citizens also acquire knowledge on how the government operates. Citizen inclusion in policy formulation ensures that the social equalities are addressed. This compels government to strive to bridge such differences through implementing social equity policies and as such, it is vital for the citizen to be part of the public policy formulation and should not be perceived as the mere spectators or targets waiting for the government to deliver the public services to them.

\subsection{Recommendations}

From the findings, the study recommends that the County Government of Mombasa should establish a participatory framework that allows citizens to monitor and evaluate development outcomes in the counties to ensure better decision making and implementation for subsequent projects and plans. Policy makers should also formulate policies that demand reporting from public participation officers to create a culture of accountability both amongst the duty bearers and those demanding accountability. The County Government of Mombasa should promote citizen participation in policy formulation, implementation and all stages of project planning to implementation. This will require capacity building for the citizens through training to ensure citizens have proper knowledge on how to create policies that will ensure achievement of effective public participation and good governance. 
International Journal of Current Aspects, Volume 5, Issue 4, 2021, PP 90-107, ISSN 2616-6976

[JCAB

\section{References}

Abraham R. M. (2014). How does Citizen Participation impact Decentralized Service Delivery? Lessons from the Kenya Local Authority Service Delivery Action Plan (LASDAP, 20022010).

Anderson, J.E. (2015). Public Policy Making: An Introduction. Boston: Hughton Mifflin

Arnstein R. A. (1969). A Ladder Of Citizen Participation, Journal of the American Institute of Planners, 35(4), 216-224

Azfar J. (2011). Community participation in Italian regional governments. IRIS working paper \# 256, University of Maryland

Barnett (1991). Quantitative and qualitative approaches. Nairobi: Acts Press

Bekker, K. (2015). Citizen participation in Local Government. Pretoria: Van Schaik.

Berner, M.M., Amos, J.M. \& Morse, R.S. (2011). What constitutes effective citizen participation in local government? Views from city stakeholders. Public Administration Quarterly, (35), 128-163.

Berner, M.M., Amos, J.M. \& Morse, R.S. (2011). What constitutes effective citizen participation in local government? Views from city stakeholders. Public Administration Quarterly, (35), 128- 163.

Bjork \& Johansson, (2001). The governance Theory, London: Routledge

Boivin, D. (2014). Citizen's Charters: Service Quality Chameleons, Public Management Review 7 (3), pp. 321-340.

Burton, P. (2017) 'Conceptual, theoretical and practical aspects in measuring the impact of citizen participation in policy making.' Paper presented to 'Citizen Participation in Policy Making' CINEFOGO conference, Bristol.

Buse K, Mays N,. \& Walt G. (2012). Making health policy. 2nd ed. Maidenhead: Open University Press.

Campbell, H. \& Marshall, R. (2000). Public involvement and planning: looking beyond the one to the many. International Planning Studies, 5(3), 321-344.

Campbell, K., \& Marshall, J. (2017). Public value: the missing ingredient in reform?, in Bentley, T., Wilson, J. (Eds), The Adaptive State, Demos, London, pp.124-31.

Carman, E., Panw, J. C. \& Wessels, J. S. (2015). Foundation of public administration. Hong Kong: University Press.

Churchill (1991). Research methods: Quantitative and qualitative approaches. Nairobi: Acts Press.

Cleophas N. K., \& \& Ephantus K. (2016). Factors Affecting the Effectiveness of Public Participation in County Governance in Kenya: A Case of Nairobi County, International Journal of Scientific and Research Publications, 6(10).

Cloete, F. (2016). Improving public policy. Pretoria: Van Schaik

Conklin E., Vroom, V.H. \& Jago A.G. (2015). The New Leadership : Managing Participation in Organisations. Englewood Cliffs: Prentice Hall.

Cristina H., \& Bianca R. (2016). Citizen Participation in the Decision Making Process at Local and County Levels in the Romanian Public Institutions, Transylvanian Review of Administrative Sciences, No. 31E/2010 pp. 76-92

Curtain, R. (2016). What Role for citizens in Developing and Implementing Public Policy? Forthcoming in Canberra Bulletin of Public Administration, Australian Public Policy Research Network, p.6 
International Journal of Current Aspects, Volume 5, Issue 4, 2021, PP 90-107, ISSN 2616-6976

[JCAB

Davids, I. (2018). Voices from Below, Reflections on Ten Years of Public Participation: The Case of Local Government in the Western Cape Province. Cape Town: Foundation for Contemporary Research.

Devas, N. \& Grant, U. (2015). Local Government Decision Making - Citizen Participation and Local Accountability: Some evidence from Kenya and Uganda. Public Administration and Development, 23(4), 307-16.

Doornbos, W. (2001). The politics and economics of public policy: An introductory analysis with cases. Homewood : Dorsey

ERDSC. (2014). Citizen Participation in Policy Making. Final Report, Yerevan.

Fiszbein R. (2017). Community participation for effective local governments in Colombia. World Development, 25(7), 1029-1043.

Fox, L., \& Meyer, P., (2015). Public and Development Management. Bellville: Stellenbosch University, p. 13

Gabriele A. (2017). Citizen Involvement in Public Policy-making: Does it Improve Democratic Legitimacy and Accountability? The Case of pTA, Interdisciplinary Information Sciences, 13(1), 103-116

Gaventa, J. \& McGee, R. (2017). Citizen action and national policy reform: Making change happen. Chigago: Zed Books.

Gisselquist, R. M. (2012) : Good governance as a concept, and why this matters for development policy, WIDER Working Paper, No. 2012/30, ISBN 978-92-9230-493-5, The United Nations University World Institute for Development Economics Research (UNU-WIDER), Helsinki

Halachmi, A.M \& Marc H. R. (2010). Citizen Participation and Performance Measurement: Operationalizing Democracy through Better Accountability. Public Administration Quarterly 34 (3): 378-99.

Hallman, H. W. (2016). Administrative Decentralization and Citizen Control. Pamphlet No. 7. Washington, D. C.: Centre for Governmental Studies.

Harrison, M. (2005). Citizen Science: a study of people. London: Routledge.

Hart, D. K. (2012). 'Theories of Government Related to Decentralization and Citizen Participation'. Public Administration Review, 32, 603-621, Special Issue.

Holmes, B. (2011). Citizens' engagement in policymaking and the design of public services, Research Paper No.1, Parliamentary Library, Parliament of Australia, 1(3),16-39.

Howlett, M. \& Mukherjee, I. (2014). Policy Design and Non-Design: Towards a Spectrum of Policy Formulation Types, Politics and Governance, 2(2), 57-71, DOI: 10.17645/pag.v2i2

Howlett, M. \& Mukherjee, I., (2017). Policy Formulation: Where Knowledge Meets Power in the Policy Process, in M. Howlett and I. M Mukherjee (ed.) Handbook of Policy Formulation, Northampton: Edward Elgar Publishing.

Howlett, M. (2015) Designing Public Policies: Principles and Instruments. London and New York: Routledge.

International Peace building Advisory Team, (2015). Public Participation in Public Decisions: New Skills and Strategies for Public Managers. California: Jossen-Bass.

International Peace building Advisory Team. (2015). Public Participation and Citizen Engagement: Effective Advising State Building Contexts - How, Geneva, an Initiative interpeace, pp. 3, 7 .

Irvin, R.A. \& Stansbury, J. (2014). Citizen Participation in Decision Making: Is It Worth the Effort? Public Administration Review, 64(1),58. 
International Journal of Current Aspects, Volume 5, Issue 4, 2021, PP 90-107, ISSN 2616-6976

[JCAB

Isham A., \& Kähkönen N. (2016). Community participation in development projects: $a$ sociological study. (unpublished M.A thesis). Port Elizabeth: University of Port Elizabeth

Joppe, M. (2012) Migrant workers: Challenges and opportunities in addressing tourism labour shortages. Tourism Management, 33(3), pp.662-671.

KHRC \& SPAN (2010). Harmonization of Decentralized Development in Kenya: Towards Alignment, Citizen Engagement and Accountability, Kenya Human Rights Commission (KHRC) \& Social and Public Accountability Network (SPAN).

Korir, D. K. \& Kipkemboi, F. (2014). The impact of school environment and peer influence on students' academic performance in Vihiga County, Kenya. International Journal of Humanities and Social Science, 4(5), 240-251..

Kotze, H \& Kellerman, A. (2013). Development Administration and Management: A Holistic Approach. Pretoria: Van Schaik.

Leedy, S, Brynard, P \& Hanekorn, N. (2017). Public Administration in contemporary society. A South African Perspective. Revised edition. Pretoria: Southern.

Mansuri, G. \& Rao, V. (2013). Reviewing participatory programs in many developing countries including Nepal and India. Critical Review of International Social and Political Philosophy, 16(2), DOI: 10.1080/13698230.2012.757918.

Markus, G, (2018). Civic Engagement in American Cities: Who, What, When, Why and so what? Report of Preliminary Findings at the 2018 Batten Symposium Panel Presentation. Pew Centre for Civic Journalism

Matharu, T., Sullivan, H. \& Skelcher, C. (2016). The mobilization, inclusion and construction of actors in European governance networks. Paper presented to 'Citizen Participation in Policy Making' CINEFOGO conference, Bristol.

Michels, A. (2011). Innovations in democratic governance: how does citizen participation contribute to a better democracy? International Review of Administrative Sciences, 77 (2), 275-293.

Mkandawire, T. (2014) Social Policy in a Development Context. New York: Palgrave Macmillan. DOI : $10.1057 / 9780230523975$

Molokwane T., \& Lukamba M. T. (2018). Citizen Involvement in the Formulation of Public Policy, The 3rd Annual International Conference on Public Administration and Development Alternatives 04 - 06 July 2018, Stellenbosch University, Saldahna Bay, South Africa

Mugenda M. O. \& Mugenda A. (2008). Research Methods: Qualitative and Quantitative Approaches. Nairobi, Kenya, African Centre for Technology Studies.

Naidoo, C. \& Ramphal R. R. (2018). The Factors That Affect Public Participation for Effective Municipal Service Delivery: A Case of Ward Committees. South African Journal of Industrial Engineering, 29(4), 82-93

Obasi, I.N., \& Lekorwe M. H. (2014). Citizen Engagement in Public Policy Making Process in Africa: The Case of Botswana, Public Policy and Administration Research, 4(3), 1-11

Peters, B. G. (2015) Advanced Introduction to Public Policy. Cheltenham: Edward Elgar Publishing.

Rakodi, C. (2016). Representation and Responsiveness-Urban politics and the poor in ten cities in the south. Community Development Journal. 39 (3), 252-265.

Restall A., \& Kaufert R. (2011). Civil Service Reform in Africa: Mixed Results After 10 Years'. International Monetary Fund. Finance and Development, 35(2). 
Rondinelli, D. A. (2015). Government Decentralization in Comparative Perspective: Theory and Practice in Developing Countries. International Review of Administrative Sciences, XLVII (2), 133-145.

Sharma, K. C. (2019a). Traditional Leadership and Contemporary Public Administration: The Case of Botswana'. In Valsan, E. H. ed. Democracy, Decentralization and Development, Brussels: IASIA.

Sharma, K.C. (2019b). Botswana: Decentralization for Democratization and Strengthening of Local Government'. In P. S. Reddy ed. Local Government, Democratization and Decentralization: A Review of Southern African Experience, Cape Town: Juta and Co. Commonwealth Journal of Local Governance, 6, 135- 142.

Talpin D. (2017). Participatory budgeting in Spain, France and Italy. GenCses, 4, 97-115.

UNDP (2017). Local Governance for Poverty Reduction: The Case of Botswana. Country Report prepared for The Fifth Africa Governance Forum: AGF-V. Maputo.

Veal, O., T., \& Darcy (2012). Analysis of public decisions. London: Render.

Wolf R., Norris, P., \& Nwana, E. (2014). Sampling Process. Chicago: Milton.

This is an open-access article published and distributed under the terms and conditions of

the cc) (i) unless otherwise stated. Access, citation and distribution of this article is allowed with full recognition of the authors and the source. Authors seeking to publish with an Internationally Peer Reviewed Journals should consider https://www.ijcab.org/ by writing to the Editor at editor@ijcab.org or submitting online at https://journals.ijcab.org/journals/index.php. The articles must be quality and meet originality test. 